\title{
Peran Usaha Pembibitan Sapi Potong Program Pemberdayaan Ekonomi Rakyat (Perak) dan Strategi Pengembangannya di Kabupaten Ngada
}

\section{Role of Cattle Breeding Economic Empowerment Program and Its Development Strategies in Ngada District}

\author{
R. L. R. Rimbing ${ }^{1}$, M. Krova ${ }^{2}$, dan M. Y. Luruk ${ }^{2}$ \\ Program Pascasarjana, Prodi Ilmu Peternakan, Universitas Nusa Cendana, \\ Jln Adisucipto Penfui, Kupang 85001 \\ ${ }^{1}$ Mahasiswa Pascasarjana Prodi Ilmu Peternakan \\ ${ }^{2}$ Dosen Pascasarjana Prodi Ilmu Peternakan \\ Corresponding e-mail: ronalrepu@ymail.com
}

\begin{abstract}
This research aims to: 1) identify the role of the Cattle Breeding Economic Empowerment Program in enhancing production output of beef cattle; 2) identify the role of Cattle Breeding Economic Empowerment Program in enhancing the income of the cattle breeders; 3 ) identify and analyze factors that influence the development of the cattle breeding program; 4) identify and analyze factors that influence the economy of the cattle breeders; and 5) formulate a development strategy for the Cattle Breeding Economic Empowerment Program. This research was conducted in 3 sub-districts, 6 villages, and 8 business groups of the Cattle Breeding Economic Empowerment Program in Ngada District. The research locations were selected from a purposive sampling technique upon active business groups. Total research informants accounts for 52 people out of a population of 2.466 from the Cattle Breeding Economic Empowerment Program of year 2011. Method of analyze undertook quantitative (correlatio-regression) and qualitative descriptive styles, continued with a SWOT analyze. Research results point that: 1) the Cattle Breeding Economic Empowerment Program provides positive contribution towards the development of cattle breeding in Ngada District, which resulted in a rise of $10 \%$ of the whole cattle production output; 2) the Cattle Breeding Economic Empowerment Program provides positive contribution towards the income of cattle breeders in Ngada District, with an $18 \%$ rise of income; 3$)$ calving interval $\left(\mathrm{X}_{5}\right)$ partially influence the development of cattle breeding in terms of cattle production output (95\% confidence level); 4) cattle sold $\left(\mathrm{X}_{5}\right)$ partially and positively influences the increase of income of the cattle breeders $(99 \%$ confidence level); 5) proposed strategy for the development of the Cattle Breeding Economic Empowerment Program in Ngada encompasses enhancement in cattle breeding output, development of human resources, optimization of natural resources, implementation of technology, development of marketing efforts, and sustainability of the cattle breeding business it self.
\end{abstract}

Key words: cattle breeding, economic empowerment program, production, income, business, development strategies

\begin{abstract}
ABSTRAK
Penelitian ini bertujuan untuk: 1) mengetahui peran usaha pembibitan sapi potong program PERAK terhadap peningkatan populasi sapi potong; 2) mengetahui peran usaha pembibitan sapi potong program PERAK terhadap pendapatan peternak; 3) mengetahui dan menganalisis faktor-faktor yang mempengaruhi tingkat perkembangan populasi pembibitan sapi potong program PERAK; 4) mengetahui dan menganalisis faktor-faktor yang mempengaruhi tingkat pendapatan peternak pembibitan sapi potong program PERAK ; dan 5) merumuskan strategi pengembangan usaha pembibitan sapi potong program PERAK. Penelitian dilakukan pada 3 kecamatan, 6 desa atau kelurahan, dan 8 kelompok usaha pembibitan sapi potong program PERAK di Kabupaten Ngada. Pemilihan lokasi ditentukan secara purposive dengan pertimbangan kelompok yang masih aktif. Responden penelitian sebanyak 52 orang dari total 2.466 orang peternak pembibitan sapi potong program PERAK dan difokuskan pada responden penerima program PERAK tahun 2011.Metode analisis yang digunakan adalah deskriptif kualitatif dan deskriptif kuantitatif (korelasi-regresi) dan analisis SWOT. Hasil penelitian menunjukkan bahwa: 1) peran usaha pembibitan sapi potong program PERAK memberikan kontribusi terhadap perkembangan populasi sapi potong di Kabupaten Ngada sebesar 10\% dari total populasi; 2) peran usaha pembibitan sapi potong program PERAK memberikan kontribusi terhadap pendapatan peternak pembibitan sapi
\end{abstract}


potong program PERAK di Kabupaten Ngada sebesar 18\% dari total pendapatan peternak; 3) hasil uji-t membuktikan bahwa secara parsial dengan tingkat keyakinan 95\% faktor calving interval $\left(\mathrm{X}_{5}\right)$ berpengaruh. sangat nyata terhadap perkembangan populasi pembibitan sapi potong program PERAK; 4) hasil uji-t membuktikan bahwa secara parsial dengan tingkat keyakinan 99\% faktor jumlah ternak sapi yang dijual $\left(\mathrm{X}_{4}\right)$ berpengaruh sangat nyata terhadap pendapatan peternak pembibitan sapi potong program PERAK; dan 5) strategi yang dapat diterapkan dalam pengembangan usaha pembibitan sapi potong pembibitan program PERAK di Kabupaten Ngada adalah strategi peningkatan populasi ternak sapi potong pembibitan program PERAK, peningkatan kualitas sumberdaya manusia, optimalisasi penggunaan sumberdaya alam, pengembangan dan penerapan teknologi, pengembangan pemasaran, dan strategi keberlanjutan usaha ternak sapi potong program PERAK.

Kata kunci: Program PERAK, populasi, pendapatan, usaha pembibitan sapi potong, strategi pengembangan

\section{PENDAHULUAN}

Kabupaten Ngada merupakan salah satu Kabupaten di Provinsi NTT yang memiliki potensi untuk pengembangan ternak sapi potong. Hal ini didukung oleh populasi ternak sapi potong yang terus meningkat setiap tahun, dimana jumlah populasi sapi potong pada tahun 2013 sebanyak 26.388 ekor dan padang penggembalaan yang luas (17.258 ha) (BPS NTT, 2014). Pemerintah Daerah Kabupaten Ngada melalui Dinas Peternakan telah banyak meluncurkan berbagai program bantuan pengembangan ternak sapi potong kepada kelompok masyarakat dengan tujuan peningkatan populasi dan pendapatan peternak. Namun dalam pengembangan ternak sapi potong ada beberapa permasalahan yang dihadapi sehingga tujuan peningkatan populasi dan pendapatan peternak tidak optimal. Permasalahan tersebut antara lain: sistem pemeliharaan tradisional dan minim teknologi, peternak menempatakan usaha sapi potong sebagai usaha sampingan, dan skala usaha ternak sapi potong yang masih kecil dan berpencarpencar (Dinas Peternakan Kabupaten Ngada, 2016)

Salah satu strategi Pemerintah Daerah Kabupaten Ngada dalam meningkatkan produktivitas dan produksi ternak sapi potong, meningkatkan pendapatan peternak, menjadikan Kabupaten Ngada sebagai daerah penghasil ternak sapi potong, dan mendukung program swasembada daging sapi tahun 2014, adalah melalui kebijakan program pemberdayaan ekonomi rakyat (PERAK) usaha pembibitan sapi potong (Pedoman Umum PERAK, 2011). Sasaran penerima program ini adalah kepala keluarga miskin sesuai dengan kriteria yang dikeluarkan oleh BPS dan kriteria khusus menurut perspektif budaya lokal di Kabupaten Ngada. Program ini sudah dijalankan sejak tahun 2011 hingga tahun 2015 yang melibatkan 114 kelompok, 2.528 kepala keluarga miskin yang tersebar di 9 Kecamatan dan 100 Desa/Kelurahan dengan jumlah ternak sapi potong sebanyak 2.716 ekor (188 ekor sapi jantan dan 2.528 ekor sapi betina produktif) (Dinas Peternakan Kabupaten Ngada, 2015).

Hasil observasi lapangan menunjukkan bahwa, peran usaha pembibitan sapi potong program PERAK mengalami peningkatan populasi pada tahun 2016 sebesar 3.648 ekor dari 2.716 ekor ternak betina yang dikembangkan. Pertambahan populasi ini belum sesuai dengan target yang ditetapkan oleh pemerintah sebesar 5.432 ekor pada tahun 2016 (Petunjuk Teknis Pelaksanaan PERAK, 2011). Peran usaha ini terhadap peningkatan populasi sapi potong yang tidak signifikan dan belum memenuhi target dari pemerintah, diduga disebabkan oleh beberapa faktor antara lain: (1) peternakan sapi potong pembibitan pada umumnya dilakukan oleh peternak kecil, minim keterampilan dan penguasaan teknologi; (2) sistem pemeliharaannya masih tradisional atau semi intensif dengan ciri 
minim input dan teknologi; (3) pelayanan kesehatan yang diberikan oleh petugas teknis tidak dilakukan secara reguler dan belum menjangkau peternak yang tinggalnya jauh dari puskeswan; (4) pemberian pakan dilakukan secara cut and carry dengan jumlah dan kualitas tergantung musim.

Beberapa saran agar pengembangan sapi potong berkelanjutan menurut Winarso et al. (2005) adalah sebagai berikut: (1) perlunya perlindungan dari pemerintah daerah terhadap wilayah-wilayah kantong ternak, terutama dukungan kebijakan tentang tata ruang ternak serta pengawasan terhadap alih fungsi lahan pertanian yang berfungsi sebagai penyangga budi daya ternak; (2) pengembangan teknologi pakan terutama pada wilayah padat ternak, antara lain dengan memanfaatkan limbah hasil perkebunan dan pertanian.

Berdasarkan uraian diatas penting untuk dikaji strategi yang tepat untuk meningkatkan peran usaha pembibitan sapi potong program PERAK terhadap perkembangan populasi dan pendapatan peternak di Kabupaten Ngada. Tinggi rendahnya peran usaha pembibitan sapi potong program PERAK akan menjadi dasar dilakukan pengembangannya.

\section{METODE PENELITIAN}

Penelitian ini merupakan penelitian survei yang dirancang sebagai penelitian penjelasan (explanatory research design). Tujuan penelitian adalah untuk menjelaskan hubungan antara peubah bebas (independent variabless) dengan peubah tidak bebas (dependent variables) melalui pengujian hipotesa (Singarimbun dan Effendi, 2006). Penelitian ini telah dilaksanakan di Kabupaten Ngada, pada kelompok usaha pembibitan sapi potong program PERAK. Responden adalah peternak yang tergabung dalam wadah kelompok penerima bibit sapi potong program PERAK. Beberapa variabel yang diteliti:
Perkembangan populasi ternak sapi potong porgram PERAK (Y) (variabel dependet) dan faktor-faktor yang mempengaruhi $\left(\mathrm{X}_{\mathrm{i}}\right)$ (variabel independet): a) tingkat kebuntingan $\left.\left(\mathrm{X}_{1}\right), \mathrm{b}\right)$ tingkat kelahiran $\left.\left(\mathrm{X}_{2}\right), \mathrm{c}\right)$ tingkat kematian $\left.\left(\mathrm{X}_{3}\right), \mathrm{d}\right)$ panen pedet (net calf crop) $\left(\mathrm{X}_{4}\right)$, e) jarak kelahiran (calving interval) $\left(\mathrm{X}_{5}\right)$, dan umur penyapihan $\left(\mathrm{X}_{6}\right)$.

Pendapatan (Y) (variabel dependent) dan faktor-faktor yang mempengaruhi $\left(\mathrm{X}_{\mathrm{i}}\right)$ (variabel independet): a) jumlah kepemilikan ternak sapi potong $\left(\mathrm{X}_{1}\right)$, biaya kandang $\left(\mathrm{X}_{2}\right)$, biaya obat-obatan $\left(\mathrm{X}_{3}\right)$, jumlah ternak sapi potong yang dijual $\left(\mathrm{X}_{4}\right)$, dan pendapatan non $\operatorname{PERAK}\left(\mathrm{X}_{5}\right)$.

Populasi merupakan keseluruhan pengamatan di Kabupaten Ngada yang menjadi perhatian dalam penelitian dan telah menerima bantuan pembibitan sapi potong program PERAK sejak tahun 2011-2014. Populasi ini tersebar di 10 Kecamatan di Kabupaten Ngada. Jumlah populasi yang telah menerima bantuan pembibitan sapi potong program PERAK adalah sebanyak 2.466 orang di 120 Desa/Kelurahan pada 137 kelompok. Populasi sasaran adalah seluruh anggota kelompok usaha pembibitan sapi potong program PERAK berjumlah 100 orang yang telah menerima bantuan ternak sapi potong pembibitan program PERAK pada rentangan waktu tahun 2011-2014 yang tersebar di 3 Kecamatan contoh pada 6 Desa/Kelurahan dan 8 kelompok. Penentuan sampel dilakukan secara purposive. Setiap kecamatan contoh akan diambil 2 desa contoh dan setiap desa contoh diambil 2 kelompok contoh dengan jumlah responden 5-11 orang yang terwakili dari responden yang terbatas hanya 8-21 orang berdasarkan data pada Dinas Peternakan Kabupaten Ngada. Penentuan sejumlah 5-11 responden contoh terpilih dari masing-masing kelompok terpilih dilakukan secara acak proporsional sehingga diperoleh 52 responden representatif. 
Sumber data penelitian terdiri atas dua bagian, yaitu: 1) data primer adalah data yang didapat langsung dari responden contoh; dan 2) data sekunder adalah data primer yang dihimpun dan disajikan oleh pihak lain dalam hal ini Dinas Teknis pengelola program PERAK. Metode yang digunakan dalam pengambilan data adalah metode survey dan alat pengumpul data yang digunakan kuesioner. Pengumpulan data dilakukan dengan beberapa metode: 1) wawancara langsung kepada pemilik dan pelaksana program PERAK dan responden yang menjadi sampel penelitian dengan menggunakan kuesioner terstruktur; 2) observasi yaitu pengumpulan data yang dilakukan dengan melakukan pengamatan langsung ke lokasi kelompok untuk mengamati kondisi responden secara langsung; dan 3) studi pustaka adalah metode pengumpulan data dengan cara meneliti dokumen-dokumen awal perencanaan kegiatan.

Metode analisis yang digunakan dalam penelitian ini adalah deskriptif kualitatif dan deskriptif kuantitatif (korelasiregresi) dan analisis SWOT. Terdiri dari lima bagian, yaitu:

Kontribusi usaha pembibitan sapi potong program PERAK terhadap total perkembangan populasi sapi potong di Kabupaten Ngada dapat dihitung dengan menggunakan rumus:

$\frac{\Sigma \text { Sapi Program PERAK (ST) }}{\Sigma \text { Sapi Program PERAK (ST) }+\Sigma \text { Sapi Non PERAK (ST) }} \times 100 \%$

Kontribusi pendapatan usaha pembibitan sapi potong program PERAK terhadap total pendapatan peternak dengan menggunakan rumus: $\frac{\text { Pend. Usaha Sapi Pot. Program PERAK (Rp) }}{\text { Pend. Usaha Sapi Program PERAK (Rp) + Pend. Non PERAK (Rp) }} x 100 \%$

Analisis faktor-faktor yang mempengaruhi perkembangan populasi ternak sapi potong pembibitan pogram
PERAK, dianalisis dengan pendekatan uji statistik regresi linier berganda sebagai berikut:

$$
\begin{gathered}
Y=a+b_{1} X_{1}+b_{2} X_{2}+b_{3} X_{3}+b_{4} X_{4}+b_{5} X_{5} \\
+b_{6} X_{6}+e_{i}
\end{gathered}
$$$$
\text { dimana: }
$$

$$
\begin{array}{ll}
\mathrm{Y} & =\text { perkembangan populasi } \\
\mathrm{X}_{1} & =\text { tingkat kebuntingan } \\
\mathrm{X}_{2} & =\text { tingkat kelahiran } \\
\mathrm{X}_{3} & =\text { tingkat kematian pedet } \\
\mathrm{X}_{4} & =\text { panen pedet (net calf crop) } \\
\mathrm{X}_{5} & =\text { jarak kelahiran (calving interval) } \\
\mathrm{X}_{6} & =\text { umur penyapihan } \\
\mathrm{a} & =\text { parameter estimasi yaitu intersep atau } \\
& \text { konstanta } \\
\mathrm{b}, \mathrm{c} & =\text { parameter-parameter yang dianalisis. } \\
\mathrm{e} & =\text { variabel pengganggu atau kesalahan } \\
& \text { (disturbances/error terms). }
\end{array}
$$

Alisis faktor-faktor yang mempengaruhi pendapatan peternak pembibitan sapi potong program PERAK, dianalisis dengan pendekatan uji statistik regresi linier berganda sebagai berikut:

$$
\begin{gathered}
Y=a+b_{1} X_{1}+b_{2} X_{2}+b_{3} X_{3}+b_{4} X_{4}+b_{5} X_{5} \\
+e_{i}
\end{gathered}
$$

dimana:

$$
\begin{array}{ll}
\mathrm{Y} & =\text { pendapatan peternak } \\
\mathrm{X}_{1} & =\text { jumlah kepemilikan ternak } \\
\mathrm{X}_{2} & =\text { biaya kandang } \\
\mathrm{X}_{3} & =\text { biaya obat-obatan } \\
\mathrm{X}_{4} & =\text { jumlah ternak sapi yang dijual } \\
\mathrm{X}_{5} & =\text { pendapatan non PERAK } \\
\mathrm{a} & =\text { parameter estimasi yaitu intersep atau } \\
& \text { konstanta } \\
\mathrm{b}, \mathrm{c} & =\text { parameter-parameter yang dianalisis. } \\
\mathrm{e} & =\text { variabel pengganggu atau kesalahan } \\
& \text { (disturbances/error terms). }
\end{array}
$$

Strategi pengembangan usaha pembibitan sapi potong program PERAK dalam meningkatkan populasi ternak sapi potong program PERAK dan pendapatan peternak menggunakan analisis SWOT kualitatif. 


\section{HASIL DAN PEMBAHASAN}

\section{Kontribusi usaha pembibitan sapi potong program PERAK terhadap total populasi sapi potong dan total pendapatan peternak di Kabupaten Ngada}

Tabel 2. Kontribusi Usaha Pembibitan Sapi Potong Program PERAK terhadap Total Populasi Sapi Potong dan Total Pendapatan Peternak di Kabupaten Ngada Tahun 2017

\begin{tabular}{llll}
\hline No & Populasi Ternak Sapi Potong & Jumlah & Kontribusi (\%) \\
\hline 1 & $\begin{array}{l}\text { Jumlah ternak sapi potong pembibitan } \\
\text { program PERAK tahun 2015 }\end{array}$ & 3.648 & 10 \\
\hline 2 & $\begin{array}{l}\text { Jumlah ternak sapi potong non usaha } \\
\text { pembibitan sapi potong program } \\
\text { PERAK tahun 2015 }\end{array}$ & 33.081 & 90 \\
\hline Total Populasi Ternak Sapi Potong & 36.729 & 100 \\
\hline & Sumber Pendapatan & $\begin{array}{l}\text { Rata-Rata Pendapatan } \\
\text { (Rp/ekor/Tahun) }\end{array}$ & Kontribusi (\%) \\
\hline 3 & $\begin{array}{l}\text { Usaha Pembibitan Sapi Potong } \\
\text { Program PERAK: }\end{array}$ & 2.785 .000 & 18 \\
\hline 4 & $\begin{array}{l}\text { Usahjalan Non Pembibitan Sapi Potong } \\
\text { Program PERAK: }\end{array}$ & 12.650 .000 & 82 \\
\hline Penjualan Hasil Kopi & 15.435 .000 & 100 \\
\hline Total Pendapatan Peternak & & \\
\hline Sumber : Data Primer, 2017 (diolah) &
\end{tabular}

Sumber : Data Primer, 2017 (diolah)

Berdasarkan Tabel 2. menunjukkan bahwa kontribusi dari usaha pembibitan sapi potong program PERAK terhadap total populasi sapi potong di Kabupaten Ngada adalah sebesar $10 \%$. Jika dilihat dari besaran kontribusi ini, dapat dikatakan bahwa kontribusinya relatif kecil terhadap populasi total sapi potong di Kabupaten Ngada. Hal ini disebabkan peternak pembibitan sapi potong program PERAK belum secara optimal menerapkan manajemen reproduksi ternak yang baik yang terlihat dari jarak kelahiran (calving interval) yang panjang (rata-rata 17 bulan), dan penyapihan pedet yang lama (rata-rata 10 bulan) sehingga berdampak pada rendahnya tingkat kelahiran dan panen pedet. Menurut Santosa (2001) bahwa salah satu faktor yang menyebabkan rendahnya tingkat kelahiran yang rendah adalah jarak kelahiran (calving interval) yang panjang dan umur penyapihan pedet yang lama.

Kontribusi usaha pembibitan sapi potong program PERAK terhadap pendapatan peternak di Kabupaten Ngada
(Tabel 2) selama satu tahun adalah sebesar $18 \%$. Kontribusi ini lebih rendah dari usaha ternak sapi potong yang dilakukan petani peternak di Kabupaten Kupang yang memberikan kontribusi terhadap pendapatan peternak sebesar 30-70\% (Sobang, 2005). Rendahnya kontribusi ini disebabkan karena sebagian besar peternak pembibitan sapi potong program PERAK memiliki kualitas sumberdaya manusia yang rendah (46\%) tamatan SD, sistem pemeliharaan secara tradisional, jumlah ternak yang dijual sangat sedikit (rata-rata 1 ekor/peternak/tahun), dan orientasinya belum sepenuhnya bersifat bisnis dan biasanya dilakukan sebagai usaha sambilan yang tidak terlalu mementingkan keuntungan secara finansial. Selanjutnya Suryanto (2004) menyatakan bahwa usaha ternak yang memberikan peran dibawah 30 persen dari total pendapatan pada umumnya dilakukan sebagai usaha sambilan. Sedangkan Hartono dan Rohaeni (2014) menyatakan bahwa kontribusi pendapatan usaha sapi potong rakyat berkisar antara 15$25 \%$. 


\section{Analisis faktor-faktor yang mempengaruhi perkembangan populasi ternak sapi potong pembibitan program PERAK di Kabupaten Ngada}

Tabel 3. Korelasi antara perkembangan populasi ternak sapi potong pembibitan program PERAK (Y) dengan faktor-faktor yang diidentifikasi (X) pada usaha pembibitan sapi potong program PERAK di Kabupaten Ngada

\begin{tabular}{llll}
\hline Variabel & Populasi $(\mathrm{Y})$ & Signifikansi & Keterangan \\
\hline Tingkat Kebuntingan $\left(\mathrm{X}_{1}\right)$ & $-0,452$ & 0.000 & sangat nyata \\
Tingkat Kelahiran $\left(\mathrm{X}_{2}\right)$ & 0,182 & 0.099 & tidak nyata \\
Tingkat Kematian $\left(\mathrm{X}_{3}\right)$ & 0,318 & 0.011 & sangat nyata \\
Net Calf Crop $\left(\mathrm{X}_{4}\right)$ & $-0,523$ & 0.000 & sangat nyata \\
Calving Interval $\left(\mathrm{X}_{5}\right)$ & $-0,874$ & 0.000 & sangat nyata \\
Umur Sapih $\left(\mathrm{X}_{6}\right)$ & $-0,711$ & 0.000 & sangat nyata \\
\hline
\end{tabular}

Sumber : Data Primer, 2017 (diolah)

Hasil korelasi Tabel 3. menunjukkan bahwa dari enam faktor yang diidentifikasi ternyata lima faktor masing-masing tingkat kebuntingan $\left(\mathrm{X}_{1}\right)$, tingkat kematian $\left(\mathrm{X}_{3}\right)$, net calf crop $\left(\mathrm{X}_{4}\right)$, calving interval $\left(\mathrm{X}_{5}\right)$ dan umur penyapihan $\left(\mathrm{X}_{6}\right)$ memiliki signifikansi lebih kecil dari taraf nyata $(\alpha)=0.05$ bahkan lebih kecil dari $\alpha=0.01$. Hal ini berarti bahwa faktor-faktor tersebut memiliki korelasi yang sangat nyata. Selanjutnya faktor tingkat kelahiran $\left(\mathrm{X}_{2}\right)$ memiliki signifikansi 0,099 dan lebih besar dari $\alpha=0.05$. Ini berarti bahwa faktor tingkat kelahiran memiliki korelasi yang tidak nyata $(\mathrm{P}>0.05)$, sehingga faktor tersebut tidak dilibatkan dalam analisis regresi. Karena $\mathrm{r} \mathrm{YX}_{4}$ memiliki koefisien korelasi tertinggi dibandingkan dengan $\mathrm{r} \mathrm{YX}_{1}$ dan $\mathrm{r} \mathrm{YX}_{3}$, maka dalam analisis regresi selanjutnya yang digunakan adalah faktor net calf crop $\left(\mathrm{X}_{4}\right)$ saja karena sudah mewakili tingkat kebuntingan $\left(\mathrm{X}_{1}\right)$ dan tingkat kematian $\left(\mathrm{X}_{3}\right)$. Dengan demikian maka dalam analisis regresi hanya melibatkan tiga faktor saja yaitu net calf crop $\left(\mathrm{X}_{4}\right)$, calving interval $\left(\mathrm{X}_{5}\right)$, dan umur sapih $\left(\mathrm{X}_{6}\right)$.
Analisis koefisien regresi dengan metode OLS, diperoleh koefisien regresi sebagai berikut: $a=7,224 ; b_{4}=0,011 ; b_{5}=$ 0,$222 ; \quad b_{6}=-0,066$. Dengan demikian persamaan regresi yang diperoleh sebagai berikut:

$$
\mathrm{Y}=7,224+0,011 \mathrm{X}_{4}-0,222 \mathrm{X}_{5}-0,066 \mathrm{X}_{6}
$$

Dari persamaan tersebut diketahui bahwa terdapat satu faktor yang sangat nyata mempengaruhi perkembangan populasi sapi potong di Kabupaten Ngada yaitu calving interval $\left(\mathrm{X}_{5}\right)-0,222$. Hal ini berarti bahwa apabila calving interval bertambah satu bulan akan menyebabkan menurunnya populasi sapi potong sebesar 0,222 satuan (ceteris paribus). Tanda negatif ini menunjukkan pengaruh yang tidak searah antara calving interval dengan perkembangan populasi sapi potong, dimana jika calving interval diperpanjang maka populasi sapi potong akan berkurang dan sebaliknya jika calving interval diperpendek maka populasi sapi potong akan bertambah.

Tabel 4. Daftar sidik ragam faktor-faktor yang mempengaruhi perkembangan populasi sapi potong pembibitan program PERAK di Kabupaten Ngada

\begin{tabular}{llllllll}
\hline $\begin{array}{l}\text { Sumber } \\
\text { keragaman }\end{array}$ & $\begin{array}{l}\text { derajad } \\
\text { bebas }\end{array}$ & $\begin{array}{l}\text { Jumlah } \\
\text { kuadrat }\end{array}$ & $\begin{array}{l}\text { Kuadrat } \\
\text { Tengah }\end{array}$ & F hitung & $\begin{array}{l}\text { Ftabel } \\
0,05\end{array}$ & 0,01 & Sig. \\
\hline Regresi & 3 & 20.582 & 6.861 & 88.266 & 2,80 & 4,22 & $.000^{\mathrm{a}}$ \\
Eror & 48 & 3.731 & .078 & & & & \\
Total & 51 & 24.313 & & & & & \\
\hline
\end{tabular}

Sumber : Data Primer, 2017 (diolah) 
Menurut Iskandar dan Farizal (2011) menyatakan bahwa produktifitas ternak sapi ditentukan antara lain oleh jarak beranak, semakin pendek jarak beranak, maka makin produktif induk sapi tersebut.

Hasil perhitungan uji $\mathrm{F}$ pada Tabel 4. diperoleh $\mathrm{F}_{\text {hitung }}$ lebih besar dari $\mathrm{F}_{\text {tabel }}$ pada tingkat kepercayaan $99 \%$ dan memiliki signifikansi lebih kecil dari $\alpha(0,01)$. Berdasarkan hasil perhitungan tersebut maka disimpulkan bahwa seluruh variabel bebas mempunyai pengaruh terhadap perkembangan populasi sapi potong program PERAK di Kabupaten Ngada. Hal ini berarti bahwa hipotesis nol $\left(\mathrm{H}_{0}\right)$ yang menyatakan tidak ada pengaruh dari faktor-faktor yang diidentifikasi terhadap perkembangan populasi sapi potong program PERAK ditolak.

Koefisien determinasi berganda $\left(\mathrm{R}^{2}\right)$ dari persamaan regresi adalah 0,847 . Hal ini berarti bahwa variasi atau keragaman perkembangan populasi ternak sapi potong pembibitan program PERAK dapat dijelaskan secara bersama-sama oleh faktorfaktor net calf crop $\left(\mathrm{X}_{4}\right)$, calving interval $\left(\mathrm{X}_{5}\right)$, dan umur sapih $\left(\mathrm{X}_{6}\right)$ sebesar $84,7 \%$, sedangkan sisanya $15,30 \%$ dijelaskan oleh faktor-faktor lain yang tidak diperhitungkan dalam model.
Berdasarkan hasil uji-t pada Tabel 5. membuktikan bahwa hanya ada satu variabel yang berpengaruh sangat nyata terhadap perkembangan populasi sapi potong pembibitan program PERAK pada tingkat kepercayaan 95\%. Variabel tersebut adalah calving interval $\left(\mathrm{X}_{5}\right)$, sedangkan variabel lain berpengaruh tidak nyata terhadap perkembangan populasi sapi potong pembibitan program PERAK. Pada tingkat kepercayaan 95\% untuk variabel calving interval $\left(\mathrm{X}_{5}\right)$ didapat $\mathrm{t}_{\text {hitung }}$ lebih besar dari $t_{\text {tabel}}$, serta memiliki nilai signifikansi lebih kecil dari $\alpha(0,01)$. Hal ini dapat dikatakan bahwa $\mathrm{H}_{0}$ ditolak dan koefisien calving interval signifikan secara statistik, sehingga dapat disimpulkan bahwa ada pengaruh yang sangat nyata antara calving interval dengan perkembangan populasi sapi potong pembibitan program PERAK di Kabupaten Ngada. Dengan demikian maka pada tataran pelaksanaan usaha pembibitan sapi potong program PERAK, peternak sebagai pelaku usaha serta para pihak yang berkompoten dalam program pengembangan pembibitan sapi potong perlu memperhatikan manajemen reproduksi yang berkaitan dengan calving interval ternak sapi potong.

Tabel 5. Koefisien regresi dan taraf nyata koefisien regresi perkembangan populasi sapi potong pembibitan program PERAK

\begin{tabular}{llllllll}
\hline & \multicolumn{6}{l}{ Unstandardized } & \multicolumn{2}{c}{$\begin{array}{c}\text { Standardized } \\
\text { Coefficients }\end{array}$} \\
\hline Model & & $\mathrm{B}$ & Std. Error & Beta & $\mathrm{t}_{\text {hitung }}$ & $\mathrm{t}_{\text {tabel }}(0,050)$ & Sig. \\
\hline 1 & (Constant) & 7.224 & 0.352 & & 20.522 & 2,010 & 0.000 \\
& Net Calf Crop & -0.011 & 0.004 & -0.178 & -2.869 & & 0.006 \\
& Interval Lahir & -0.222 & 0.025 & -0.642 & -8.772 & & 0.000 \\
& Umur Sapih & -0.066 & 0.017 & -0.27 & -3.806 & & 0.000 \\
\hline
\end{tabular}

A. Dependent Variable: Populasi

Sumber: Data primer, 2017 (diolah) 


\section{Analisis faktor-faktor yang mempengaruhi pendapatan peternak pembibitan sapi potong program PERAK di Kabupaten Ngada}

Tabel 6. Koefisien korelasi dan tingkat nyata antara pendapatan peternak pembibitan sapi potong program PERAK (Y) dengan faktor-faktor yang mempengaruhi di Kabupaten Ngada $\left(\mathrm{X}_{\mathrm{i}}\right)$

\begin{tabular}{llll}
\hline & Y & Signifikansi & Keterangan \\
\hline $\mathrm{X}_{1}$ & $0.364^{*}$ & 0.037 & Nyata \\
$\mathrm{X}_{2}$ & $0,420^{*}$ & 0.018 & Nyata \\
$\mathrm{X}_{3}$ & $0,008^{\mathrm{TN}}$ & 0.485 & Tidak nyata \\
$\mathrm{X}_{4}$ & $0.819^{* *}$ & 0.000 & Sangat nyata \\
$\mathrm{X}_{5}$ & $0.126^{\mathrm{TN}}$ & 0.274 & Tidak nyata \\
\hline
\end{tabular}

Sumber: Data primer (diolah), 2017

Berdasarkan Tabel 6. menunjukkan bahwa dari lima faktor yang didentifikasi dan diduga berpengaruh terhadap pendapatan peternak pembibitan sapi potong program PERAK ternyata hanya tiga faktor yang memiliki korelasi yang signifikan dengan pendapatan peternak yakni faktor jumlah ternak yang dimiliki $\left(\mathrm{X}_{1}\right)$, biaya kandang $\left(\mathrm{X}_{2}\right)$ dan jumlah ternak yang dijual $\left(\mathrm{X}_{4}\right)$. Dua faktor lain yaitu biaya obat-obatan $\left(\mathrm{X}_{3}\right)$ dan pendapatan non perak $\left(\mathrm{X}_{5}\right)$ tidak memiliki korelasi yang kuat dengan pendapatan peternak pembibitan sapi potong program PERAK. Oleh karena itu maka dalam analisis regresi hanya tiga faktor tersebut yang memiliki korelasi yang signifikan yang dilibatkan dalam analisis.

Analisis koefisien regresi dengan metode OLS diperoleh koefisien regresi sebagai berikut: $\mathrm{a}=-4.546 .000 ; \mathrm{b}_{1}=$ $596.444,89 ; b_{2}=6,269 ; b_{4}=6.210 .000$. Dengan demikian persamaan regresi yang diperoleh adalah sebagai berikut:
$\mathrm{Y}=-4.546 .000-596.444,89 \mathrm{X}_{1}+6,269 \mathrm{X}_{2}+$ $6.210 .000 \mathrm{X}_{4}$

Dari persamaan tersebut diketahui bahwa terdapat satu faktor yang sangat nyata mempengaruhi pendapatan peternak pembibitan sapi potong program PERAK di Kabupaten Ngada yaitu jumlah ternak yang dijual $\left(\mathrm{X}_{4}\right)$ 6.210.000. hal ini berarti bahwa apabila jumlah ternak yang dijual bertambah satu ekor maka pendapatan peternak akan bertambah sebesar Rp. 6.210 .000 (ceteris paribus). Tanda positif ini menunjukkan pengaruh yang searah antara jumlah ternak yang dijual $\left(\mathrm{X}_{4}\right)$ dengan pendapatan peternak, dimana jika jumlah ternak yang dijual banyak maka pendapatan peternak akan semakin besar dan sebaliknya jika jumlah ternak yang dijual sedikit maka pendapatan peternak akan sedikit. Rusdiana et al, (2010) dan Rizqina (2011) yang menegaskan bahwa semakin banyak ternak sapi yang dijual maka akan semakin banyak keuntungan yang diterima oleh peternak.

Tabel 7. Daftar sidik ragam faktor-faktor yang mempengaruhi pendapatan peternak pembibitan sapi potong program PERAK di Kabupaten Ngada

\begin{tabular}{llllllll}
\hline Model & Derajad & Jumlah & Kuadrat & $\mathrm{F}_{\text {hitung }}$ & $\mathrm{F}_{\text {tabel }}$ & & Sig \\
\cline { 6 - 8 } & Bebas & Kuadrat & Tengah & & 0,05 & 0,01 & \\
\hline Regresi & 3 & $4,751 \mathrm{E} 13$ & $1,584 \mathrm{E} 13$ & 19,157 & 3,07 & 4,87 & $.000^{\mathrm{a}}$ \\
Eror & 21 & $1,736 \mathrm{E} 13$ & $8,268 \mathrm{E} 11$ & & & & \\
Total & 24 & $6,488 \mathrm{E} 13$ & & & & & \\
\hline
\end{tabular}

Sumber : Data Primer, (diolah), 2017 
Hasil perhitungan uji $\mathrm{F}$ pada Tabel 7. diperoleh nilai $F_{\text {hitung }}$ lebih besar dari $F_{\text {tabel }}$ pada tingkat kepercayaan $95 \%$ dan memiliki nilai signifikansi lebih kecil dari $\alpha(0,01)$. Berdasarkan hasil perhitungan tersebut, maka disimpulkan bahwa seluruh variabel bebas mempunyai pengaruh terhadap pendapatan peternak pembibitan sapi potong program PERAK di Kabupaten Ngada. Hal ini berarti bahwa hipotesis nol $\left(\mathrm{H}_{0}\right)$ yang menyatakan tidak ada pengaruh dari faktor-faktor yang diidentifikasi terhadap pendapatan peternak pembibitan sapi potong program PERAK ditolak.

Koefisien determinasi berganda $\left(\mathrm{R}^{2}\right)$ dari persamaan regresi adalah 0,732 . Hal ini berarti bahwa variasi atau keragaman pendapatan peternak pembibitan sapi potong program PERAK dapat dijelaskan secara bersama-sama oleh ketiga faktor yang diidentifikasi tersebut sebesar 73,20\% sedangkan sisanya $26,80 \%$ dijelaskan oleh faktor-faktor lain yang tidak diperhitungkan dalam model.

Berdasarkan hasi uji-t pada Tabel 8 . menunjukkan bahwa hanya ada satu variabel yang berpengaruh sangat nyata terhadap pendapatan peternak pembibitan sapi potong program PERAK pada tingkat kepercayaan 95\%. Variabel tersebut adalah jumlah ternak yang dijual $\left(\mathrm{X}_{4}\right)$, sedangkan variabel lain berpengaruh tidak nyata terhadap pendapatan peternak pembibitan sapi potong program PERAK. Pada tingkat kepercayaan 95\% untuk variabel jumlah ternak yang dijual $\left(\mathrm{X}_{4}\right)$ didapat $t_{\text {hitung }}$ lebih besar dari $t_{\text {tabel}}$, serta memiliki nilai signifikansi lebih kecil dari $\alpha$ $(0,01)$. Hal ini dapat dikatakan bahwa $\mathrm{H}_{0}$ ditolak dan jumlah ternak yang dijual $\left(\mathrm{X}_{4}\right)$ signifikan secara statistik, sehingga dapat disimpulkan bahwa ada pengaruh yang sangat nyata antara jumlah ternak yang dijual $\left(\mathrm{X}_{4}\right)$ dengan pendapatan peternak pembibitan sapi potong program PERAK di Kabupaten Ngada. Saputra (2012) menyatakan bahwa penerimaan usaha peternakan rakyat dipengaruhi oleh banyaknya jumlah ternak sapi yang dipelihara dan jumlah ternak sapi yang dijual. Dengan demikian peternak sebagai pelaku usaha, harus berusaha untuk meningkatkan jumlah ternak yang dijual apabila ingin meningkatkan pendapatannya, dengan sayarat manajemen pemeliharaan sapi harus baik.

\section{Strategi pengembangan usaha pembibitan sapi potong program PERAK dalam meningkatkan populasi sapi potong dan pendapatan peternak di Kabupaten Ngada}

Perumusan strategi pengembangan usaha pembibitan sapi potong program PERAK di Kabupaten Ngada melalui analisis SWOT diawali dengan mengidentifikasi kekuatan, kelemahan, peluang dan ancaman yang dimiliki kelompok usaha pembibitan sapi potong program PERAK di Kabupaten Ngada. Kelompok usaha pembibitan sapi potong program PERAK dalam penelitian ini pada dasarnya memiliki kekuatan, kelemahan, peluang, dan ancaman yang sama.

Tabel 8. Koefisien regresi dan taraf nyata koefisien regresi pendapatan peternak pembibitan sapi potong program PERAK di Kabupaten Ngada

\begin{tabular}{llllll}
\hline \multirow{2}{*}{ Model } & \multicolumn{2}{l}{ Unstandardized Coefficients } & \multirow{2}{*}{ Sig. } \\
\cline { 2 - 3 } & $\mathrm{B}$ & Std. Error & & \\
\hline 1 & (Constant) & $-4,546 \mathrm{E} 6$ & $1,150 \mathrm{E} 6$ & $-3,954$ & 0,001 \\
& Jumlah ternak $\left(\mathrm{X}_{1}\right)$ & $-59.644,89$ & $771.275,24$ & $-0,773$ & 0,448 \\
& B. Kandang $\left(\mathrm{X}_{2}\right)$ & 6.269 & 4,765 & 1,316 & 0,203 \\
& Ternak yang dijual $\left(\mathrm{X}_{4}\right)$ & $6,210 \mathrm{E} 6$ & $958.346,21$ & 6,480 & 0,000 \\
\hline
\end{tabular}

a. Dependent Variable: INC_PERAK

Sumber : Data Primer, 2017 (diolah) 
Tabel 9. Hasil identifikasi analisis faktor internal dan eksternal pengembangan usaha pembibitan sapi potong program PERAK di Kabupaten Ngada

\begin{tabular}{|c|c|c|}
\hline $\begin{array}{l}\text { Faktor } \\
\text { Internal }\end{array}$ & Kekuatan (Strenghts) & Kelemahan (Weakness) \\
\hline & $\begin{array}{l}\text { Peternak pembibitan sapi potong } \\
\text { program PERAK usia produktif ( } 50 \% \\
\text { responden berusia } 40-50 \text { tahun) } \\
\text { Tenaga kerja dalam keluarga peternak } \\
\text { tersedia (rata-rata } 1 \text { orang) } \\
\text { Lahan pakan untuk sapi potong tersedia } \\
(56 \% \text { responden memiliki luas lahan } 10- \\
20 \text { are) } \\
\text { Tersedia berbagai Jenis HMT } \\
\text { Tersedia limbah hasil pertanian untuk } \\
\text { pakan sapi potong } \\
\text { Pengalaman beternak sapi potong cukup } \\
\text { lama ( } 48 \% \text { responden memiliki } \\
\text { pengalaman beternak sapi } 2-5 \text { tahun) }\end{array}$ & $\begin{array}{l}\text { Kualitas SDM peternak rendah }(46 \% \\
\text { responden berpendidikan tamatan SD) } \\
\text { Kontribusi usaha usaha pembibitan sapi } \\
\text { potong program PERAK terhadap total } \\
\text { pendapatan peternak rendah }(18 \%) \\
\text { Jarak kelahiran (calving interval) yang } \\
\text { panjang (rata-rata } 17 \text { bulan) } \\
\text { Umur penyapihan pedet yang lama (rata- } \\
\text { rata } 10 \text { bulan) } \\
\text { Jumlah ternak sapi potong yang dijual } \\
\text { sedikit (rata-rata } 1 \text { ekor/tahun) }\end{array}$ \\
\hline $\begin{array}{l}\text { Faktor } \\
\text { Eksternal }\end{array}$ & Peluang (Opportunities) & Ancaman (Weakness) \\
\hline & $\begin{array}{l}\text { Bibit ternak sapi potong program } \\
\text { PERAK umur produktif (12-24 bulan) } \\
\text { dan tersedia } \\
\text { Permintaan pasar ternak sapi potong } \\
\text { terus meningkat } \\
\text { Dukungan kebijakan pengembangan } \\
\text { ternak sapi potong dari Pemerintah } \\
\text { Tersedianya bantuan modal dari } \\
\text { pemerintah } \\
\text { Usaha pembibitan sapi potong program } \\
\text { PERAK memberikan kontribusi sebesar } \\
10 \% \text { terhadap total populasi sapi potong } \\
\text { di Kabupaten Ngada } \\
\text { Adanya program swasembada daging } \\
\text { sapi tahun } 2014\end{array}$ & $\begin{array}{l}\text { Tuntutan kualitas, kuantitas, dan } \\
\text { kontinuitas produk peternakan } \\
\text { Semua peternak pembibitan sapi potong } \\
\text { program PERAK merupakan keluarga } \\
\text { miskin dengan tingkat pendidikan yang } \\
\text { rendah } \\
\text { Terbukanya jaringan perdagangan bebas } \\
\text { kurangnya pendampingan dan pengawasan } \\
\text { dari dinas teknis yang membidangi fungsi } \\
\text { peternakan terhadap kelompok usaha } \\
\text { pembibitan sapi potong program PERAK di } \\
\text { Kabupaten Ngada } \\
\text { Ada usaha sejenis di daerah lain }\end{array}$ \\
\hline
\end{tabular}

Sumber : Data Primer, 2017 (diolah)

\section{Alternatif strategi pengembangan usaha pembibitan sapi potong program PERAK di Kabupaten Ngada}

Penentuan alternatif strategi yang sesuai bagi pengembangan usaha pembibitan sapi potong program PERAK adalah dengan membuat matriks SWOT berdasarkan faktorfaktor internal maupun eksternal yang terdiri dari kekuatan (strength), kelemahan (weakness), peluang (opportunity), dan ancaman (threath). Kombinasi dan perpaduan antara faktor internal dan eksternal tersebut akan dapat diperoleh beberapa alternatif strategi yang dapat diterapkan dalam pengembangan usaha pembibitan sapi potong program PERAK di Kabupaten Ngada.

Berdasarkan matriks SWOT maka disusun empat strategi utama yaitu SO, WO, ST, dan WT. Alternatif strategi bagi pengembangan usaha pembibitan sapi potong program PERAK dapat dilihat pada Tabel 10 di bawah ini. 
Tabel 10. Matriks analisis SWOT pengembangan usaha pembibitan sapi potong program PERAK di Kabupaten Ngada

\begin{tabular}{|c|c|c|}
\hline $\begin{array}{l}\text { INTERNAL } \\
\text { (IFAS) }\end{array}$ & 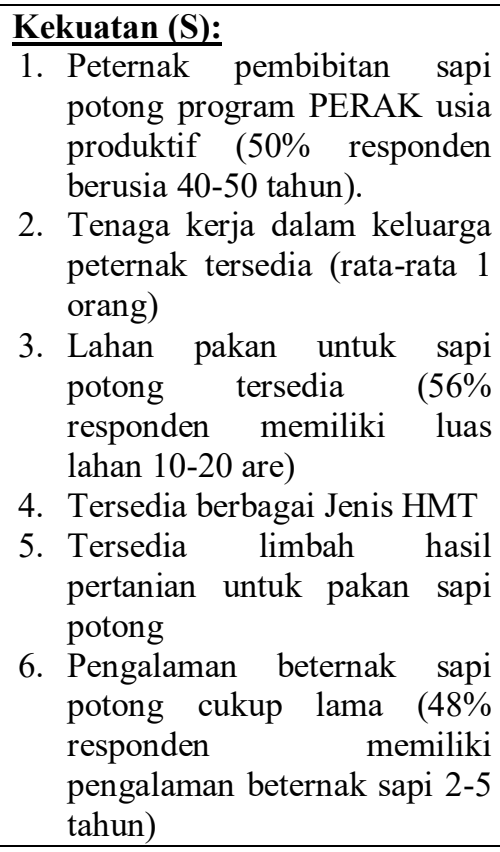 & $\begin{array}{l}\text { Kelemahan }(\mathbf{W}) \text { : } \\
\text { 1. } \text { Kualitas SDM peternak rendah } \\
(46 \% \text { responden berpendidikan } \\
\text { tamatan SD) } \\
\text { 2. Kontribusi usaha usaha } \\
\text { pembibitan sapi potong program } \\
\text { PERAK terhadap total } \\
\text { pendapatan peternak rendah } \\
(18 \%) \\
\text { 3. Jarak kelahiran (calving interval) } \\
\text { yang panjang (rata-rata 17 bulan) } \\
\text { 4. Umur penyapihan pedet yang } \\
\text { lama (rata-rata 10 bulan) } \\
\text { 5. Jumlah ternak sapi potong yang } \\
\text { dijual sedikit (rata-rata 1 } \\
\text { ekor/tahun) }\end{array}$ \\
\hline $\begin{array}{l}\text { Peluang (O): } \\
\text { 1. Bibit ternak sapi potong } \\
\text { pembibitan program PERAK } \\
\text { umur produktif (12-24 bulan) } \\
\text { 2. Permintaan pasar ternak sapi } \\
\text { potong terus meningkat. } \\
\text { 3. Dukungan kebijakan } \\
\text { pengembangan ternak sapi } \\
\text { potong dari Pemerintah. } \\
\text { 4. Tersedianya bantuan modal } \\
\text { dari pemerintah } \\
\text { 5. Usaha ternak sapi potong } \\
\text { pembibitan program PERAK } \\
\text { memberikan kontribusi } \\
\text { sebesar 10\% terhadap total } \\
\text { populasi ternak sapi potong di } \\
\text { Kabupaten Ngada } \\
\text { 6. Usaha ternak sapi potong } \\
\text { pembibitan program PERAK } \\
\text { memberikan kontribusi } \\
\text { sebesar } 18 \% \text { terhadap total } \\
\text { pendapatan peternak sapi } \\
\text { potong pembibitan program } \\
\text { PERAK di Kabupaten Ngada } \\
\text { 7. Adanya program swasembada } \\
\text { daging sapi tahun } 2014\end{array}$ & 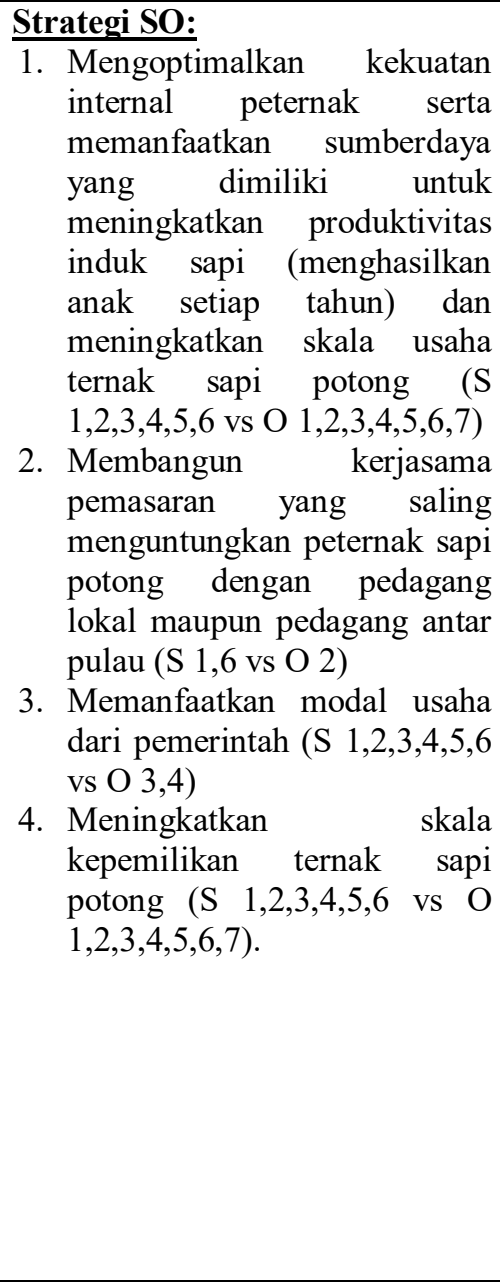 & 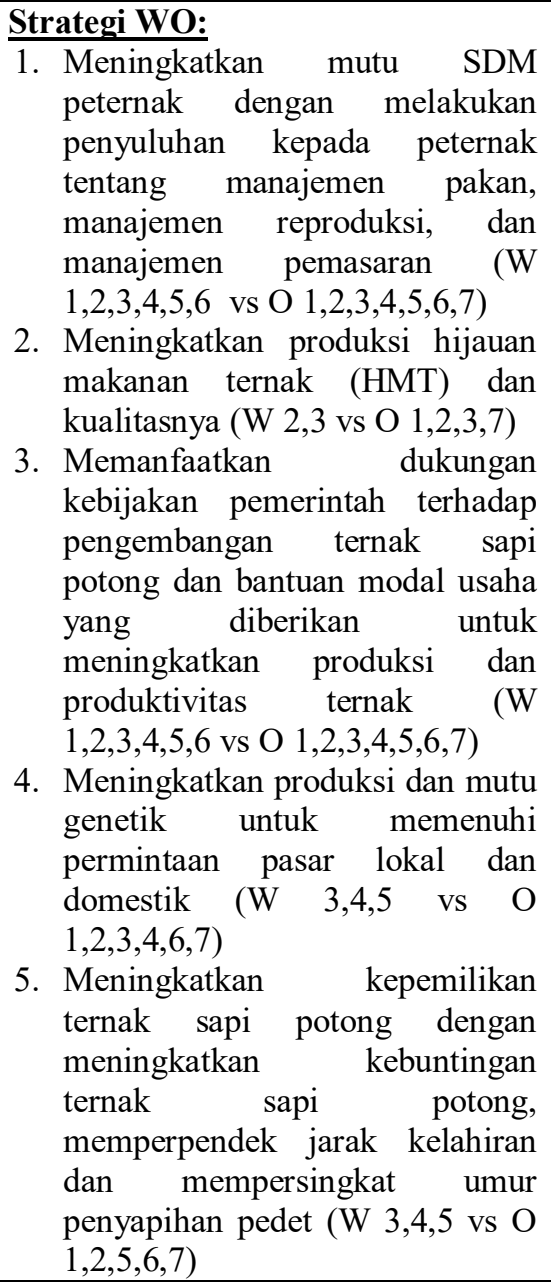 \\
\hline
\end{tabular}




\begin{tabular}{|l}
\hline \multicolumn{3}{|l|}{ Ancaman (T): } \\
1. $\begin{array}{l}\text { Tuntutan kualitas, kuantitas, } \\
\text { dan kontinuitas produk }\end{array}$ \\
peternakan \\
2. Semua peternak sapi potong \\
pembibitan program PERAK \\
merupakan keluarga miskin \\
dengan tingkat pendidikan yang \\
rendah \\
3. Terbukanya \\
perdagangan bebas \\
4. kurangnya pendampingan dan \\
pengawasan dari dinas teknis \\
yang membidangi fungsi \\
peternakan terhadap kelompok \\
usaha ternak sapi potong \\
pembibitan program PERAK di \\
Kabupaten Ngada \\
5. Ada usaha sejenis di daerah lain
\end{tabular}

5. Ada usaha sejenis di daerah lain

\section{Strategi ST:}

1. Memanfaatkan teknologi IB untuk meningkatkan mutu genetik ternak sapi potong ( $\mathrm{S}$ $1,2,3,4,5,6$ vs $\mathrm{T} 1,3,4,5)$

2. Menyediakan jantan pemacek yang unggul secara genetik untuk kawin alam (S $1,2,3,4,5,6$ vs $\mathrm{T} 1,4,5)$

3. Perlu adanya bantuan tambahan berupa ternak unggas dan benih tanaman hortikultura untuk menopang kebutuhan hidup peternak dan keberlanjutan usaha ternak sapi potong (S 1, 2, 3, 4, 5, 6 vs T $2,3,4)$

4. Mengoptimalkan peran petugas PUSKESWAN untuk melakukan tugas pokok dan fungsinya dengan baik. ( $\mathrm{S}$ $1,2,3,4,5,6$ vs T 4$)$

\section{Strategi WT:}

1. Peningkatan mutu SDM peternak melalui pendidikan dan pelatihan manajamen produksi dan reproduksi (W 1,2,3,4,5,6 vs $\mathrm{T}$ $1,2,3,4)$

2. Memantau perkembangan harga ternak sapi potong di pasaran (W $1,3,6$ vs T 3,4,6)

3. Menjamin keberlanjutan usaha ternak sapi potong dengan usaha tambahan berupa ternak unggas dan tanaman hortikultura (W 1, 3 vs T $2,3,4,5$ )

4. Meningkatkan mutu genetik ternak sapi potong melalui teknologi IB dan melaksanakan kegiatan penunjang lainnya seperti; perbaikan pakan, vaksinasi, memperpendek jarak kelahiran dan mempersingkat umur penyapihan pedet (W $1,2,3,4,5,6$ vs T $1,2,3,4,5)$

Sumber : Data Primer, 2017 (diolah)

Berdasarkan matriks analisis SWOT di atas diperoleh beberapa alternatif strategi yang dapat diterapkan dalam pengembangan usaha pembibitan sapi potong program PERAK di Kabupaten Ngada di masa yang akan datang sebagai berikut:

Strategi peningkatan populasi sapi potong program PERAK, melalui kegiatan:

1. Peningkatan produktivitas induk sapi agar menghasilkan pedet setiap tahun, memperpendek jarak kelahiran dan mempersingkat umur penyapihan pedet

2. Perbaikan mutu genetik ternak dengan teknologi Inseminasi Buatan (IB) dan Intesifikasi Kawin Alam (Inka)

3. Peningkatan pengetahuan peternak melalui pendidikan dan pelatihan tentang manajemen produksi dan reproduksi ternak sapi potong

4. Strategi Peningkatan Kualitas Sumberdaya Manusia (SDM), melalui kegiatan:

5. Penyuluhan, pendidikan dan pelatihan pengolahan pakan ternak, penanganan gangguan reproduksi dan kesehatan ternak, manajemen produksi dan reproduksi, serta manajemen pemasaran

\section{Optimalisasi peran petugas Puskeswan}

Strategi Optimalisasi Penggunaan Sumberdaya Alam (SDA), melalui kegiatan:

1. Optimalisasi penggunaan sumberdaya lahan

2. Optimalisasi produksi dan pemanfaatan pakan unggul serta pemanfaatan limbah pertanian dan sumber pakan alternatif

3. Peningkatan produksi hijauan makanan ternak (HMT) dan kualitasnya

4. Strategi Pengembangan dan Penerapan Teknologi, melalui:

5. Optimalisasi penyuluhan kepada peternak tentang pentingnya IB dalam memperbaiki mutu genetik ternak sapi potong

6. Pengembangan pilot project usaha ternak sapi potong

7. Penyediaan sarana dan prasarana pendukung usaha ternak sapi potong

8. Pelatihan kepada peternak tentang teknologi IB dan pengolahan pakan ternak sapi potong

9. Strategi Pengembangan Pemasaran, melalui kegiatan:

10. Pemantauan perkembangan harga ternak sapi potong di pasaran 
11. Pelatihan kepada peternak tentang teknologi IB dan pengolahan pakan ternak sapi potong

12. Strategi Pengembangan Pemasaran, melalui kegiatan:

13. Pemantauan perkembangan harga ternak sapi potong di pasaran

14. Menjalin hubungan kerjasama yang saling menguntungkan antara peternak dengan pedagang lokal maupun pedagang antar pulau

15. Strategi Keberlanjutan Usaha Pembibitan Sapi Potong Program PERAK, melalui kegiatan:

16. Perbaikan mutu genetik ternak sapi potong program PERAK dengan teknologi IB dan kawin alam menggunakan pejantan unggul

17. Penambahan bantuan lain selain ternak sapi potong yaitu berupa ternak unggas dan atau tanaman holtikultura

\section{KESIMPULAN}

Peran usaha pembibitan sapi potong program PERAK di Kabupaten Ngada terhadap perkembangan populasi dan pendapatan peternak rendah (kontribusinya hanya $10 \%$ dari total populasi dan $18 \%$ dari total pendapatan peternak). Faktor-faktor yang berpengaruh terhadap rendahnya peran usaha pembibitan sapi potong program PERAK terhadap populasi dan pendapatan peternak adalah net calf crop $\left(\mathrm{X}_{4}\right)$, calving interval $\left(\mathrm{X}_{5}\right)$, umur sapih $\left(\mathrm{X}_{6}\right)$, dan jumlah ternak yang dijual $\left(\mathrm{X}_{4}\right)$. Strategi yang dapat diterapkan dalam pengembangan usaha pembibitan sapi potong program PERAK di Kabupaten Ngada untuk meningkatkan perannya adalah strategi peningkatan populasi sapi potong program PERAK, peningkatan kualitas sumberdaya manusia, optimalisasi penggunaan sumberdaya alam, pengembangan dan penerapan teknologi, pengembangan pemasaran, dan keberlanjutan usaha pembibitan sapi potong program PERAK.

\section{DAFTAR PUSTAKA}

Badan Pusat Statistik Kabupaten Ngada. 2016. Kabupaten Ngada Dalam Angka. Ngada. NTT.

Badan Pusat Statistik Nusa Tenggara Timur. 2014. NTT Dalam Angka.Kupang. NTT

Dinas Peternakan Kabupaten Ngada. 2016. Laporan Tahunan 2016. Ngada. NTT.

Dinas Peternakan Kabupaten Ngada . 2016. Laporan Evaluasi PERAK 2016. Ngada. NTT.

Dinas Peternakan Kabupaten Ngada . 2011. Petunjuk Teknis Pelaksanaan PERAK. Ngada. NTT.

Dinas Peternakan Kabupaten Ngada . 2011. Pedoman Umum PERAK. Ngada. NTT.

Dinas Peternakan Provinsi Nusa Tenggara Timur. 2011. Laporan Tahunan 2011. Kupang. NTT.

Dinas Peternakan Provinsi Nusa Tenggara Timur. 2017. Laporan Tahunan 2017. Kupang. NTT.

Direktorat Jenderal Peternakan dan Kesehatan Hewan. 2013. Statistik Peternakan dan Kesehatan Hewan. Kementerian Pertanian Republik Indonesia. Jakarta. http://ditjennak.pertanian.go.id.

Direktorat Jenderal Peternakan dan Kesehatan Hewan. 2017. Statistik Peternakan dan Kesehatan Hewan. Kementerian Pertanian Republik Indonesia. Jakarta.

Hartono, B and E. S. Rohaeni. 2014. Contribution to income of traditional beef catle farmer house holds in Tanah Laut Regency, South Kalimantan, Indonesia. Livestock Research for Rural Development 26 (8) 2014

Iskandar dan Farizal., 2011. Prestasi Reproduksi Sapi Persilangan yang 
Dipelihara di Dataran Rendah dan Dataran Tinggi Jambi. Fakultas Peternakan, Universitas Jambi. Volume 13 Nomor 1 Hal. 25-28. ISSN 08528349 .

Sirajudin, S.N. 2010. Analisis Biaya Transaksi pada Usaha Sapi Perah Sistem Kemitraan dan Mandiri serta Strategi Pengembangannya di Provinsi Sulawesi Selatan. Disertasi. Sekolah Pasca Sarjana Institud Pertanian Bogor. Bogor.

Statistik Peternakan dan Kesehatan Hewan, 2017. Direktorat Jenderal Peternakan dan Kesehatan Hewan Kementerian Pertanian

Winarso, B., R. Sajuti, \& C. Muslim. 2005. Tinjauan ekonomi ternak sapi potong di Jawa-Timur. Forum Penelitian Agro-Ekonomi 23:61-71

Wirdahayati, R. B. 2010. Kajian Kelayakan dan Adopsi Inovasi Teknologi Sapi Potong mendukung Program PSDS: Kasus Jawa Timur dan Jawa Barat. Posiding Seminar Nasional dan Veteriner. Bogor 3-4 Agustus 2010. Pusat Penelitian dan Pengembangan Peternakan, Bogor. hlm 339-346.

Zuman, H; Setianto, J; Utama, S.P. 2012. Keputusan Peternak Mempertahankan Sapi Lokal sebagai Usaha Ternak di Kabupaten Kaur (Studi Kasus di Desa Sekunyit dan Desa Pasar Lama, Kecamatan Kaur Selatan). Jurnal Naturalis, Penelitian dan Pengelolaan Sumber Daya Alam dan Lingkungan. Vol. 1 (2)p: 135-140. 